\title{
INTO THE ANTHROPOCENE: ENVIRONMENTAL HISTORY AND THE MORALITY OF CLIMATE CHANGE
}

ERIC PAWSON

\section{Abstract}

This article argues that the nature of landscape 'improvement' as understood in the colonial period reflected a strong sense of common purpose and collective good, and the desire to use this as the basis of modern prosperity and growth. But these are not sentiments that have been uncritically accepted for some decades as the modernist conception of the rural landscape and resource use has come under increasing attack. The central questions posed here are then: what has happened to this moral commonality, and how might we rediscover some workable elements of collective value to guide us in today's much less certain and restless Anthropocene times? This applies particularly to the issue of climate change, which is often treated as a scientific or technical problem rather than one of moral urgency. The concept of terrestrial dwelling is offered as a means of exploring where we might now find a place to stand, on an Earth that is revealing itself to be both acutely vulnerable and inconveniently active. This article discusses some incipient examples of terrestrial dwelling in Aotearoa New Zealand.

Keywords: improvement, Anthropocene, landscape, morality, climate change, terrestrial dwelling

\section{Introduction}

In 1946, the New Zealand Journal of Agriculture carried a series of images on its monthly cover. Taken together, these told a story about where it imagined the country to be in a post-war world. The storyline was strongly moralising: New Zealand was a land of neat, productive agricultural landscapes, and its mission was to feed an exhausted motherland. The March cover showed a farmer extending a supporting hand across the oceans to a British worker; for April the shipping lines to Britain were mapped, alongside a picture of pallets of food being loaded on to a freighter in Wellington harbour; by May's issue they were being unloaded in the Port of London. 
That this was seen as no romantic fantasy was revealed by the dramatic cover in July of the 4 horsemen of the apocalypse galloping through the sky above Britain, with the third (Famine) prominent beside those of Conquest, War and Death.

Perhaps the most memorable in the series is the one for September 1946 (Figure 1). It was this that Tom Brooking used as a poster to promote New Zealand's first environmental history course, at the University of Otago, in the late 1990s. It shows a young farmer ploughing on a tractor, in a well-kempt landscape of enclosed fields. His head is turned skywards, where above a line of distant mountains is an image of St Paul's in London, standing clear but ghostly amongst wartime ruins. It is a cover that says much: both for what it includes, as well as about what and whom it is silent. The artwork is typical of a tradition that at the time was used to promote New Zealand to itself and to others. When some years later we published the book from our 'Empires of grass' project, ${ }^{1}$ the chosen cover was a not dissimilar reproduction from a large painting by Marcus King. King's painting, Town and country landscape, was produced about 1950, and is a centrepiece in the environmental history exhibition at the national museum in Wellington, Te Papa Tongawera.

Douglas Lloyd Jenkins has described King as creating images of great prospect and power that spoke of a modern agrarian nation lit by a determined sun and driven by the gentle hum of the milking shed or chug of the Massey Ferguson tractor'. ${ }^{2}$ This description could equally well apply to the Journal of Agriculture covers. Such art encapsulated a progressive spirit, of a country building a national identity and forging a role in the world, atop its proud war record. It purveyed a strong sense of common purpose and collective good. The argument of this article is that this reflected the nature of landscape 'improvement' as understood in colonial New Zealand, and the desire to use this as the basis of modern prosperity and growth. But these are not sentiments that have been uncritically accepted for some decades, as the modernist conception of the farming landscape has come under increasing attack. ${ }^{3}$ The central questions to explore here are therefore: what has happened to this moral commonality, and how might we rediscover some workable elements of collective value to guide us in today's much less certain and restless Anthropocene times?

\footnotetext{
1 T. Brooking and E. Pawson, eds, Seeds of Empire: Environmental Transformation in New Zealand (London: I. B. Tauris, 2011; Bloomsbury, 2020).

2 D. Lloyd Jenkins, 'Foreword', in P. Alsop and W. Feeney, Marcus King: Painting New Zealand for the World (Nelson: Potton \& Burton, 2015), 17.

3 H. Campbell, Farming Inside Invisible Worlds: Modernist Agriculture and its Consequences (London: Bloomsbury, 2020); C. D. Meurk and S. R. Swaffield, 'A landscape ecological framework for indigenous regeneration in rural New Zealand-Aotearoa', Landscape and Urban Planning 50 (2000): 129-44.
} 


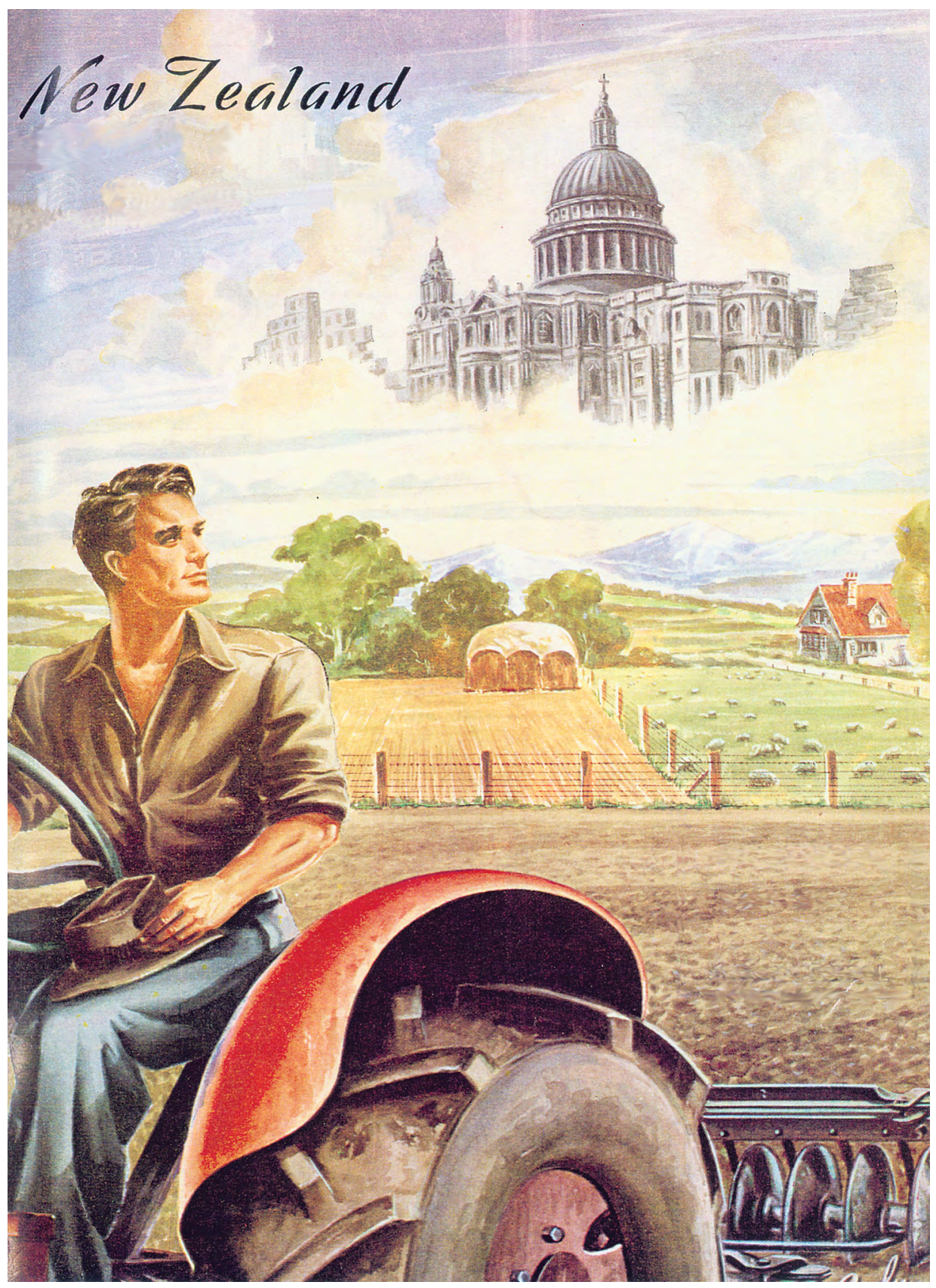

Figure 1: The front cover of the New Zealand Journal of Agriculture, September 1946.

Source: The author. 


\section{Empires of grass}

The colonial ethic of 'improvement' is so pervasive as to be mentioned frequently in written texts in environmental history, yet rarely is it indexed. It expressed a foundational Pākehā (or European) perspective on the world that the right to property depended not on custom, but on human labour to remove land from a state of nature. ${ }^{4}$ It was as basic to the precepts of Edward Gibbon Wakefield, whose colonising schemes depended on the generation of value by such means, as to the practices of missionaries and farmers working day by day to bring indigenous peoples and ecologies in line. The elemental technologies of improvement, in settler colonies like New Zealand, as in Britain, were mapping and enclosure. The agent of these technologies was the surveyor, whose work enabled the capture and internalisation of new value through the imposed landscape geometry of individualised property. ${ }^{5}$ Within the boundaries of enclosure, agricultural 'improvers' would apply specific forms of land-use practice, such as the specialised form of husbandry that is the focus of 'Empires of grass'. So specialised was it that by 1920 (more or less the end point for that project), over 90 per cent of New Zealand's exports were in some way the product of introduced pastures.

The term 'Empires of grass' ${ }^{\text {' }}$ reflects not only the national agricultural dominance by one crop, but also the single-mindedness with which farmers cleared and modified indigenous ecologies on the ground to accommodate introduced pasture plants. Their quest was actively supported by state actors, such as the Department of Agriculture, and policies like land-use intensification and the development of agricultural science. ${ }^{7}$ Bruce Levy, the head of the Grasslands Division of the Department of Scientific and Industrial Research in the middle of the twentieth century, proclaimed that 'The glorious truth is [that] more and better grass, [and] more and more stock, [is] surely the country's surest and soundest economic goal!' The resulting landscapes were the product of a transformation so rapid that they were, according to Peter Holland writing of the New Zealand province of Canterbury, 'serious [and] wholly without frivolity'. ${ }^{9}$ Kenneth Cumberland, as a newly arrived

4 E. Pawson and A. A. Christensen, 'Environmental history', in The International Encyclopedia of Geography, ed. D. Richardson et al. (Chichester and Hoboken, NJ: John Wiley \& Sons, 2017), doi.org/10.1002/9781118786352. wbieg0899.

5 A. A. Christensen, 'Mastering the land: Mapping and metrologies in Aotearoa New Zealand', in Making a New Land: Environmental Histories of New Zealand, ed. E. Pawson and T. Brooking (Dunedin: Otago University Press, 2013), 310-27.

6 'Empires of grass' was Tom Brooking's original and expressive name for the Marsden Fund project that he and I led from 2004 for some years. It resulted in a range of publications, notably a book under the title Seeds of Empire $(2011,2020)$. This title was the choice of a publisher who felt it would play better to an international audience.

7 T. Brooking, Lands for the People? The Highland Clearances and the Colonisation of New Zealand. A Biography of John McKenzie (Dunedin: University of Otago Press, 1996).

8 E. B. Levy, Grasslands of New Zealand, 3rd ed. (Wellington: Government Printer, 1970), xxx.

9 P. G. Holland, 'Plants and lowland Canterbury landscapes', in Geography for the 1980s: Proceedings, Twelfth New Zealand Geography Conference, Christchurch, January, 1983 (Christchurch: New Zealand Geographical Society, 1984), 25. 
geographer from the United Kingdom, observed in 1941 that 'What in Europe took twenty centuries, and in North America four, has been accomplished in New Zealand within a single century. ${ }^{10}$

Cumberland was as aware of some of the environmental costs of this 'accomplishment' as another pioneer in this country's environmental history, Herbert Guthrie-Smith. Cumberland undertook a comprehensive assessment of soil erosion on New Zealand's pastoral lands. ${ }^{11}$ But it was Guthrie-Smith, the Hawke's Bay sheep farmer and author, who shortly before his death agonised: 'Have I then for sixty years desecrated God's earth and dubbed it improvement?" 12 This conflict has deep-seated roots in the Pākehā mind, 'the fundamental cleavage of human from other forms of life' - that is, between ourselves and the world-having emerged as early as the Hellenistic period. ${ }^{13}$ Writing of a later time, in Man and the Natural World, Keith Thomas refers to the 'breathtakingly anthropocentric spirit in which Tudor and Stuart preachers interpreted the biblical story ${ }^{14}{ }^{14}$ In other words, although there have always been competing cultural stories, there is a consistency in the Western tradition that has reinforced belief in an Earth designed for human use, and in an insistent collective quest to 'improve' it for human ends.

Improvement therefore legitimised European colonisation as well as the thirst for cheap nature and cheap labour that characterised its worldwide domination. ${ }^{15}$ Territories occupied by people who were not improvers, such as Māori Aotearoa before European arrival, were readily deemed 'waste'. Indeed, Wakefield viewed it as 'a moral wilderness' lacking virtuous users and uses of the land, ${ }^{16}$ in Otago, for example, his plan is said to have given colonists 'the means of converting wilderness into garden'. ${ }^{17}$ The critical role of Māori in feeding early Pākehā settlements did not fit with the perspective of this mission and was quickly usurped. Nor a century later did the continued existence of Māori land in multiple ownership. As late as 1961, the notorious Hunn Report on the Department of Māori Affairs claimed

10 K. B. Cumberland, 'A century's change: Natural to cultural vegetation in New Zealand', Geographical Review 31, no. 4 (1941): 529.

11 K. B. Cumberland, Soil Erosion in New Zealand: A Geographic Reconnaissance (Wellington: Soil Conservation and Rivers Control Council, 1944).

12 H. Guthrie-Smith, 'Preface to third edition' (1940), in Tutira: The Story of a New Zealand Sheep Station, new ed. (Auckland: Random House, 1999), xxiii.

13 C. J. Glacken, Traces on the Rhodian Shore: Nature and Culture in Western Thought from Ancient Times to the End of the Eighteenth Century (Berkeley, CA: University of California Press, 1967), 708.

14 K. Thomas, Man and the Natural World: Changing Attitudes in England 1500-1800 (Harmondsworth: Penguin, 1984), 18.

15 R. Patel and J. W. Moore, A History of the World in Seven Cheap Things (Oakland, CA: University of California Press, 2017).

16 H. C. Evison, The Ngai Tahu Deeds: A Window on New Zealand History, revised ed. (Christchurch: Canterbury University Press, 2007), 38.

17 T. Brooking, 'The great escape: Wakefield and the Scottish settlement of Otago', in Edward Gibbon Wakefield and the Colonial Dream: A Reconsideration, ed. The Friends of the Turnbull Library (Wellington: GP Publications, 1997), 131. 
that 'Multiple ownership obstructs utilization, so Maori land quite commonly lies in the rough or grazes a few animals apathetically'. This inefficient use of resources, it continued, 'opposes a serious bar to the proper use of land in the interests of the Maoris [sic] themselves, not to mention the national interest'. ${ }^{18}$ Even though the report was strongly contested at the time, it took aim at a situation that sat incongruously alongside Levy's 'glorious truth' of the role of empires of grass.

Morally progressive landscapes of improvement have therefore been the basis of New Zealand's modern prosperity and its commitment to growth. Internationally, the rise of growth as a policy objective is a post-Second World War phenomenon; ${ }^{19}$ as a social metaphor, however, it has been infused with the same sense of purposive value as 'improvement'. Even though the environmental costs of growth have been questioned since at least the 1960s, it is hardly coincidental that New Zealand's collection of environmental data is patchy and erratic compared to the devotion with which long-run economic time series have been constructed..$^{20}$ The political understanding of growth has been powerfully shaped by well-known narratives such as W. W. Rostow's 5-stage model, with its emphasis on transition, take-off and mass consumption. ${ }^{21}$ Taken broadly, it captured an underlying sense of collective improvement in living standards through the trickle-down effect, described as 'a rising tide lifts all boats'. In J. K. Galbraith's retelling, 'Production has eliminated the more acute tensions associated with inequality', as 'increasing aggregate output is an alternative to redistribution'. ${ }^{22}$ In this way, economic growth was-and still iscast as part of the common good.

If growth, like 'improvement', is a modern morality tale, New Zealand-along with Australia-added an extra twist in the 1950s. This was the urge to enhance levels of primary production in order to 'feed the world' and stave off famine in wartorn Europe, and latterly in countries experiencing rapid population growth. ${ }^{23}$ This was the justification for ongoing land clearance, supported by the state through the Lands and Survey Department, and the enthusiastic acceptance of chemical farming that was the subject of Rachel Carson's Silent Spring in $1962 .{ }^{24}$ That New Zealand still retains such global pretensions, employing all possible artificial

18 J. K. Hunn, Report on Department of Maori Affairs, with Statistical Supplement (Wellington: Government Printer, 1961), 52.

19 J. Tomlinson, 'Inventing "decline": The falling behind of the British economy in the postwar years', Economic History Review 49, no. (4 (1997): 731-57.

20 Office of the Parliamentary Commissioner for the Environment, New Zealand, Focusing Aotearoa New Zealand's Environmental Reporting System (Wellington: Parliamentary Commissioner for the Environment, 2019).

21 W. W. Rostow, The Stages of Economic Growth: A Non-Communist Manifesto (Cambridge: Cambridge University Press, 1960).

22 J. K. Galbraith, The Affluent Society, 2nd ed. (Harmondsworth: Penguin, 1970), 105.

23 C. Rosin, 'Food security and the justification of productivism in New Zealand', Journal of Rural Studies 29 (2013): 50-8; B. Wildblood-Crawford, 'Grassland utopia and Silent Spring: Rereading the agrichemical revolution in New Zealand', New Zealand Geographer 62, no. 1 (2006): 65-72.

24 R. Carson, Silent Spring (Boston: Houghton Mifflin, 1962). 
enhancements to this end, is evidenced by Fonterra's business goal to be one of the world's largest dairy producers by volume, alongside an escalation in the pastoral use of nitrogenous fertilisers in the last 20 years that would make Levy proud. Over the same period, the tourism industry pursued ambitious growth targets, based quixotically on a ' $100 \%$ Pure New Zealand' campaign. By the time of the Covid-19 outbreak, tourism and dairy accounted for more than half the country's foreign exchange earnings, only recently finding their social licence to operate coming into question, as environmental and social effects intensifed. ${ }^{25} \mathrm{It}$ is anxieties such as these that characterise a new era of environmental history, the Anthropocene.

\section{Anthropocene disruptions}

The term 'Anthropocene' has gained currency in the last decade, having been used by the atmospheric scientist Paul Crutzen in Nature in 2002 to denote the recent period of Earth's history in which humans have become the driving force of planetary change. ${ }^{26}$ It stands in contrast to the 'Holocene' that geologists use to denote the last 10,000 years, during which Earth conditions have been appropriate and sufficiently consistent for human development. ${ }^{27}$ As an idea, the Anthropocene has long since escaped the confines of earth science; instead, debate has raged over when it began or whether it should rather be called something like the 'Capitalocene', which some theorists consider better identifies causality. ${ }^{28}$ Increasingly, however, analysis focuses on the global turning point represented by the 'Great Acceleration' of the 1950s and $1960 \mathrm{~s} .{ }^{29}$ It was then that a wide range of measures of human impact on the Earth system, relating to resources, population, atmospheric emissions, nuclear fallout, and chemical and water use underwent an upwards step change, alongside measures of gross domestic product, or GDP. ${ }^{30}$ From a global perspective, Rostow's 'take-off into sustained growth was very much a reflection of what was happening at the time (Figure 2).

\footnotetext{
25 R. Le Heron, 'Dairying in question', in The New Biological Economy: How New Zealanders are Creating Value from the Land, E. Pawson and the Biological Economies Research Team (Auckland: Auckland University Press, 2018), 20-40; H. C. Perkins and C. Rosin, 'Tourism, landscapes and biological resources', in The New Biological Economy, Pawson et al., 137-56; Parliamentary Commissioner for the Environment, Pristine, Popular ... Imperilled? The Environmental Consequences of Projected Tourism Growth (Wellington: Parliamentary Commissioner for the Environment, 2019).

26 P. J. Crutzen, 'Geology of mankind', Nature 415, no. 6867 (2002): 23.

27 W. Steffen et al., 'Trajectories of the Earth System in the Anthropocene', Proceedings of the National Academy of Sciences 115, no. 33 (2018): 8252-9.

28 E. Ellis, Anthropocene: A Very Short Introduction (Oxford: Oxford University Press, 2018); Patel and Moore, $A$ History of the World.

29 J. R. McNeill and P. Engelke, The Great Acceleration: An Environmental History of the Anthropocene since 1945 (Cambridge, MA: Belknap Press, 2016); K. Trebeck and J. Williams, The Economics of Arrival: Ideas for a Grown-up Economy (Bristol: Policy Press, 2019).

30 W. Steffen et al., 'The Anthropocene: conceptual and historical perspectives', Philosophical Transactions of the Royal Society A 369 (2011): 842-67.
} 


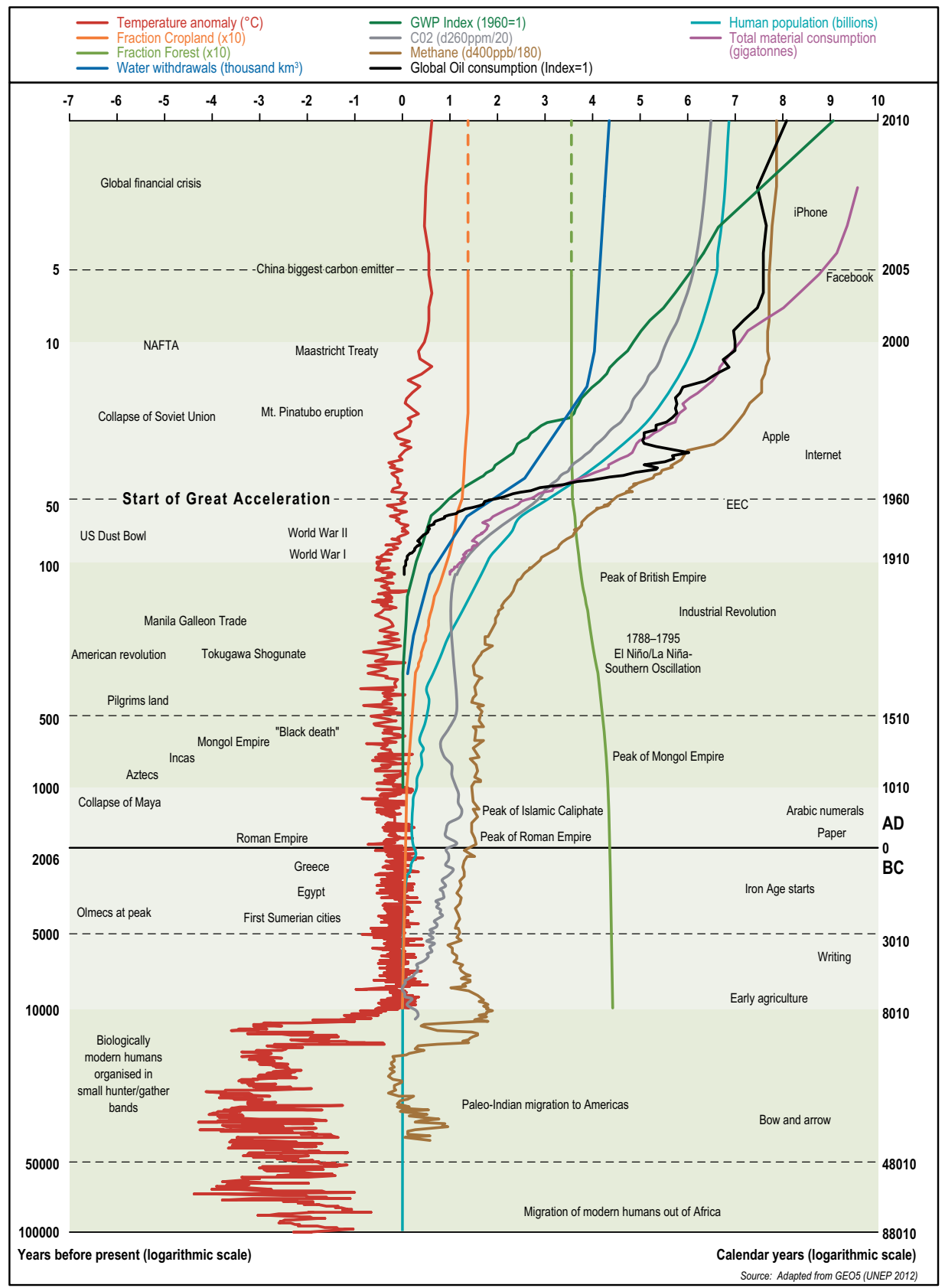

Figure 2: The Great Acceleration in historical context.

Source: Adapted from United Nations Environment Programme, GEO 5, Global Environment Outlook (2012), 22; and informed by R. Costanza et al., 'Sustainability or collapse: What can we learn from integrating the history of humans and the rest of nature?', Ambio 36, no. 7 (2007): 522-7, and W. Steffen et al., 'The trajectory of the Anthropocene: The Great Acceleration', The Anthropocene Review 2, no. 1 (2015): 81-98. 
This is the wider context of the rising intensity of resource use in New Zealand's pastoral and pre-Covid tourism industries. But globally, measures of the intensity of Anthropocene environmental impact on the ground are astonishing. A consequence of the pervasiveness of enclosure is that the world's forests are now so fractured that 70 per cent of what remains is within 1 kilometre of a forest edge. ${ }^{31}$ The implications of this for biodiversity, ecosystem function and global climate are profound. The extent of New Zealand biodiversity loss, as the direct consequence of 2 centuries of 'improvement', is well known. The rapid growth in numbers of stock units this enabled was illustrated in a stark graph in Seeds of Empire; ${ }^{32}$ it has long been a traditional part of the national story that sheep many times outnumber people, even if now to a lesser extent. New Zealand is but an extreme case of an international phenomenon where 97 per cent of the total biomass of land vertebrates is made up of humans ( 32 per cent) and their domestic animals (65 per cent). ${ }^{33}$ Creating grassland based on introduced pasture plants to accommodate these domestic animals destroys both carbon sinks and biodiversity, and current industrial systems of stock husbandry contribute significantly to the release of greenhouse gasses. In New Zealand's case, half its emissions are from agriculture, with much of the balance from motor vehicle use. ${ }^{34}$

The impact of these changes on the Earth, its atmosphere and oceans, leads to the central characteristic of the Anthropocene: its disruptiveness. Of this, climate change and the growing incidence of extreme weather events are the obvious markers, with the risk of tipping points into abrupt and irreversible change more likely than once thought possible. ${ }^{35}$ But the disruptiveness is not only of nature, but also of cultural assumptions about relations between the social and the natural, and ultimately of the practices of social life itself. It is doubly unsettling, with the Earth revealing itself as both acutely vulnerable and restlessly active. ${ }^{36}$ We are leaving behind the relatively benign consistency of the Holocene. The morally secure narratives of improvement and growth will no longer enable the universe to be inhabited with certainty and meaning: in fact, they have paradoxically undermined both certainty and meaning. The climate crisis is also 'a crisis of culture, and thus of the imagination'. ${ }^{37}$

31 N. M. Haddad et al., 'Habitat fragmentation and its lasting impact on Earth's ecosystems', Science Advances 1, no. 2 (2015).

32 Brooking and Pawson, Seeds of Empire, 10.

33 Y. Bar-on, R. Phillips and R. Milo, 'The biomass distribution on earth', Proceedings of the National Academy of Sciences 115, no. 25 (2018): 6506-11; C. Bonneuil and J.-B. Fressoz, The Shock of the Anthropocene: The Earth, History and Us (London: Verso, 2017).

34 New Zealand's unusual emissions profile is at: www.stats.govt.nz/indicators/new-zealands-greenhouse-gasemissions.

35 T. M. Lenton et al., 'Climate tipping points: Too risky to bet against', Nature 575 (2019): 592-5; Steffen et al., 'Trajectories of the Earth System'.

36 R. Macfarlane, 'Should this valley have rights?', Guardian Weekly 201, no. 22 (2019): 40-4.

37 A. Ghosh, The Great Derangement: Climate Change and the Unthinkable (Chicago: University of Chicago Press, 2016), 9. 
Two decades ago, Crutzen could argue that 'The Earth currently operates in a state without previous analogy'. ${ }^{38}$ It is becoming much clearer that its inhabitants now do as well.

For its human inhabitants, this is equivalent to 'a traumatic loss of coordinates'..$^{39}$ Bruno Latour positions this historically in pointing to the obvious: 'there is no Earth capable of containing [the modern ideals] of progress, emancipation, development'. ${ }^{40}$ Simple ecological footprint calculations indicate that several planets are already required to maintain existing-let alone desired-levels of consumption. And the strains that such desires inflict on the only planet that we have are already manifest as crises that are recurrent and global in reach, rather than manageable, regional or local as in the past. Yet what Latour describes as 'the vacuity of contemporary politics's1 is frequently organised to deny or escape these realities, in its continued commitment to the onwards-and-upwards thrust of growth and 'improvement'. ${ }^{42}$ But if there is no longer a stable framework, an Earth that is indifferent to the consequences of human material desires, how or where are we to find a place to stand?

Traditionally, an answer might have come from cultural history. Although Anthropocene writers emphasise the ontological break 'between the human being as subject of entitlement and the object of nature', ${ }^{43}$ it has long been argued that the history of people-nature relations is more complex and subtle. In contrast to a theology of 'dominion', there are recurrent threads of Arcadia as well as environmental stewardship that reflect more caring attitudes to the Earth. ${ }^{44}$ At the height of enthusiasm for colonial improvement in the nineteenth century, George Perkins Marsh issued a warning about the costs of the exploitation of nature that was widely heard. ${ }^{45}$ The Great Acceleration has seen a much broader upsurge in ecological and environmental awareness. Surely there is much to learn from such examples? Thomas long since exposed the difficulty here. In commenting on the conflict between the new sensibilities and the material foundations of human

38 P. Crutzen and W. Steffen, 'How long have we been in the Anthropocene era?', Climatic Change 61, no. 23 (2003): 253.

39 T. Morton, Hyperobjects: Philosophy and Ecology after the End of the World (Minneapolis, MN: University of Minnesota Press, 2013), 22.

40 B. Latour, Down to Earth: Politics in the New Climatic Regime (Cambridge: Polity Press, 2018), 16.

41 Latour, Down to Earth, 44.

42 An American writer has said of Australia's climate-denying politicians: 'And so maybe Australia will find itself stuck in the climate spiral, clinging ever more tightly to coal as its towns and cities choke on the ash of a burning world'. R. Meyer, 'Australia will lose to climate change', The Atlantic, 4 January 2020.

43 Bonneuil and Fressoz, The Shock of the Anthropocene, 40.

44 Glacken, Traces on the Rhodian Shore; D. Worster, Nature's Economy: The Roots of Ecology (San Francisco, CA: Sierra Club Books, 1977).

45 D. Lowenthal, 'Nature and morality from George Perkins Marsh to the millennium', Journal of Historical Geography 26, no. 1 (2000): 3-27. 
society' as manifest in early modern England, he observed that a 'mixture of compromise and concealment has so far prevented this conflict from having to be fully resolved'. ${ }^{46}$ We are now at the point where resolution is urgently required.

\section{Searching for a new morality}

If there is one characteristic of debates on climate change, it is that they tend to focus on the science and on technical solutions. But in this case, information is not power: rather it is often far too inconvenient, distancing or overwhelming for people who have become comfortable living with carbon. ${ }^{47}$ It is nearly 30 years since the first Rio Earth Summit and a multilateral commitment to the Framework Convention on Climate Change. Not only have most governments failed to act since with sufficient urgency, but most consumers have looked resolutely the other way. How else to explain trends like the second-largest contributor to global greenhouse gas emissions in the last decade being the growth in numbers of SUVs? ${ }^{48}$ In New Zealand, both SUV preferences and per capita car use are amongst the highest in the world, and road vehicle emissions have risen by over 80 per cent since $1990 .{ }^{49}$ But neither in New Zealand nor globally have emissions statistics, or warming limits based on the science of climate change, gained much traction. Hence the argument that the future of our species and planet depends on creating a mass social movement motivated by moral arguments, not statistics..$^{50}$

This position is worth exploring, given the moral framing of 'improvement' and economic growth that has underwritten the Great Acceleration. Increasingly, there are calls for 'a return to an ethically informed public conversation', ${ }^{51}$ and for an expansion of a moral imagination that has atrophied over recent decades with the self-interestedness of consumerism and individual aspiration. Robert Reich describes the common good as a compact 'not just with those who are alive today. It's also with those who have come before us and those yet to be born'. ${ }^{52}$ His concern is for a rediscovery of shared commitments to the rule of law, democratic institutions,

\footnotetext{
46 Thomas, Man and the Natural World, 303.

47 B. Hayward, Sea Change: Climate Politics and New Zealand (Wellington: Bridget Williams Books, 2017); T. Morton, Being Ecological (Cambridge, MA: MIT Press, 2018).

48 L. Cozzi and A. Petropoulos, 'Commentary', 15 October 2019. International Energy Agency, www.iea. org/commentaries/growing-preference-for-suvs-challenges-emissions-reductions-in-passenger-car-market, accessed 27 January 2020.

49 R. Maetzig, 'Two-thirds of New Zealand-new vehicles are SUVs or utes', Stuff, 10 March 2019, www.stuff. co.nz/motoring/trends-in-suvs-and-vans/110999026/twothirds-of-new-zealandnew-vehicles-are-suvs-or-utes, accessed 27 January 2020; New Zealand has around 800 light vehicles per 1,000 people (including children); in Otago and Canterbury, about 900: Ministry of Transport, Annual Fleet Statistics 2017, 7, www.transport.govt.nz/statistics-andinsights/fleet-statistics/sheet/vehicle-fleet, accessed 27 January 2020.

50 E. Beinhocker, 'I am a carbon abolitionist', Democracy: A Journal of Ideas (24 June 2019), 24, democracyjournal. org/arguments/i-am-a-carbon-abolitionist, accessed 27 January 2020.

51 T. Judt, Ill Fares the Land (New York: Penguin, 2010), 9.

52 R. B. Reich, The Common Good (New York: Alfred A. Knopf, 2018), 42.
} 
truth, equal political rights and opportunity. But the compact applies as much to what Pope Francis has called caring for our common home, in a text that is repeatedly critical of the illusions of growth. ${ }^{53}$ Marsh's warning famously identified the future generations argument in this context: people, he wrote in 1864, 'have for too long forgotten that the earth was given to [them] for usufruct alone, not for consumption, still less for profligate waste. ${ }^{54}$

There have been some valuable attempts to engage with the ethics of climate change, ${ }^{55}$ and increasingly this is shaping popular and official discourse. One writer, of the reluctance of the Australian Government to discuss the subject in the face of a devastating 2019-20 bush fire season, said that 'I can't explain this to my children in a way that makes adults seem like sane, moral actors. ${ }^{56}$ But climate justice must also apply to those living in conditions of gross inequality, whose way of life currently or historically has contributed little to the problem, and who have few resources with which to adapt to it. ${ }^{57}$ This is of growing concern not only to radical commentators but also to establishment agencies such as the World Bank, the International Monetary Fund, ${ }^{58}$ and the Intergovernmental Panel on Climate Change. The last has identified the need for 'rapid, far-reaching and unprecedented changes in all aspects of society'. ${ }^{59}$ Such changes, some argue, must move well beyond the position of 'the human being as subject of entitlement' to an empathetic recognition of humanity as an intergenerational project, ${ }^{60}$ and of the existence of other living beings with whom we share a common home, ${ }^{61}$ as well as their inherent liveliness that is oblivious to any human interest. ${ }^{62}$

How might such change be brought about, the more so when it cannot be left to individual conscience? ${ }^{63}$ In outline, 3 embryonic elements can be identified: frameworks, precedents and transitions. Frameworks can situate individuals within

53 Pope Francis, Encyclical Letter Laudato Si' of the Holy Father Francis on Care for Our Common Home (2015), w2.vatican.va/content/francesco/en/encyclicals/documents/papa-francesco_20150524_enciclica-laudato-si.html, accessed 27 January 2020.

54 G. P. Marsh, Man and Nature, ed. D. Lowenthal (first published 1864) (Cambridge, MA: Belknap Press of Harvard University Press, 1965), 36.

55 J. Garvey, The Ethics of Climate Change: Right and Wrong in a Warming World (London: Continuum, 2008); R. Attfield, Environmental Ethics: A Very Short Introduction (Oxford: Oxford University Press, 2018); T. Ord, The Precipice. Existential Risk and the Future of Humanity (London: Bloomsbury, 2020).

56 In D. Cave, 'Australia burns again, and now its biggest city is choking', New York Times, 6 December 2019.

57 Latour, Down to Earth.

58 L. Elliott, 'Tackling climate crisis is what we should be doing, says new IMF boss', The Observer, 30 November 2019.

59 Intergovernmental Panel on Climate Change, 'Summary for Policymakers of IPCC Special Report on Global Warming of $1.5^{\circ} \mathrm{C}$ approved by governments' (2018), www.ipcc.ch/2018/10/08/summary-for-policymakers-ofipcc-special-report-on-global-warming-of-1-5c-approved-by-governments, accessed 27 January 2020.

60 Ord, The Precipice.

61 M. Priest, 'Emotional ethics of warfare: how empathy can be used to strengthen protection of the natural environment' (MA diss., University of British Columbia, 2019).

62 R. Macfarlane and S. Donwood, Ness (London: Hamish Hamilton, 2018); Macfarlane, 'Should this valley have rights?'

63 Ghosh, The Great Derangement. 
wider historical, political and policy commitments, and enable them to see meaning in their own actions, whilst providing accountability for all parties. New Zealand's Zero Carbon Act 2019, with its commitment to regularly audited national carbon budgets, modelled on the British precedent, is a potential example. In response to its passage, the Australian writer Richard Flanagan commented that 'one only has to look at the global standing of New Zealand to see the power of setting a moral and practical example'. ${ }^{64}$ This overlooks the fact that its record to date is little better than Australia's, but was penned in exasperation borne of continued support of fossil fuel interests by many governments, including his own.

Precedents, like frameworks, can provide the means towards establishing some new coordinates. The success of the multilateral Montreal Protocol (1987) in containing CFC usage to protect the ozone layer is often mentioned, although the solution, being one of chemical substitution, was considerably easier than the dramatic behavioural changes required by climate change. Nonetheless, there are some successes in carbon management and available mechanisms, such as carbon pricing, carbon budgets and emissions trading schemes, are well known. These are ways to end the market failure aspect of climate change, where greenhouse gases are in effect externalities. ${ }^{65}$ More than a decade ago, the Stern Review identified the economic opportunities that transitions to post-carbon futures will open up. ${ }^{66}$ Although it is only recently that the concept of a new green deal has gained traction, this in itself is an appeal to historical precedent.

But perhaps the one thing that is necessary to underwrite transition is a new morality tale, or collective story. Many writers have urged that it is time to replace GDP as the metric of economic success, not least because access to material wealth is now so uneven. ${ }^{67}$ Katherine Trebeck and Jeremy Williams propose that rather than envisaging human progress as an endless upward trajectory after 'take-off', it is time to consider the idea of 'arrival'. This recognises that we are in reality rooted in nature and in place, and cognisant of 'the wealth that an economy and society already has' ${ }^{68}$ Wealth in this context implies well-being: encompassing social, cultural and environmental—as well as economic — values and relationships. The argument echoes that of Latour, who writes of 'landing somewhere', ${ }^{69}$ in the face of a modern system of coordinates that is caught between the attractions of globalisation that

64 R. Flanagan, 'Scott Morrison and the big lie about climate change: Does he think we're that stupid?', The Guardian, 24 November 2019.

65 J. Tirole, Economics for the Common Good (Princeton, NJ: Princeton University Press, 2017); Trebeck and Williams, The Economics of Arrival.

66 N. Stern, The Economics of Climate Change: The Stern Review (Cambridge: Cambridge University Press, 2007); High-Level Commission on Carbon Prices, Report of the High-Level Commission on Carbon Prices (Washington, DC: World Bank, 2017).

67 For example, T. Jackson, Prosperity Without Growth: Foundations for the Economy of Tomorrow, 2nd ed. (London: Routledge, 2017); K. Rowarth, Doughnut Economics: Seven Ways to Think Like a 21st-Century Economist (London: Random House, 2017).

68 Trebeck and Williams, The Economics of Arrival, 78.

69 Latour, Down to Earth, 7. 
cannot be satisfied by one planet, and the rump of the local that has been left behind by modernisation. He proposes a third, Earthbound orientation, the 'terrestrial', reflecting what he deems the crucial choice, between 'to modernize or to ecologize'.70 How might we learn to live terrestrially, within the bounds of one earth? In this context, what might morally defensible dwelling look like? And how might it sit within or alongside New Zealand's long tradition of empires of grass?

\section{Terrestrial dwelling}

The primary attribute of terrestrial dwelling is that it does not act as if emancipated from either earthly constraints or earthly liveliness. The Earth, in other words, is no longer merely a stage on which human affairs are conducted, as it was treated by colonising and modernising peoples throughout the Holocene. Nor is it any more an arena within which a Bruce Levy can dream of 'butterfat performances and stocking densities hitherto considered impossible of attainment. ${ }^{71}$ It is a new world, but 'not a new terra incognita for explorers in colonial headgear'. ${ }^{72}$ Rather it is a world that we share in common with all non-human beings, whose dynamism is not predictable in preordained ways, and inside which we cohabit with those previously deemed fit only for 'improvement'. And it is here, amongst the terrestrial adaptations of the indigenous, both people and nature, that some incipient new stories can be discerned.

One of the most remarkable is the emergence in Aotearoa New Zealand of the 'taniwha economy', a term used to recognise the extent of Māori-controlled economic activity ${ }^{73}$ The scale and range of forms of Māori land- and water-based enterprise puts the lie to the assumptions of generations of official policymaking, as highlighted by the Hunn Report, that full integration is a prerequisite to progress. Tribal ownership of resources has enabled the development of the multi-billiondollar taniwha economy, but this has not occurred in traditional ways within Latour's rump of the local. A good example is the integrated set of business activities built up by the Tuaropaki Trust, in which the regenerative principles of a circular economy ${ }^{74}$ are to the fore. The Trust has extensive lands at Mokai, west of Taupo, in New Zealand's central North Island, on which its geothermal station provides power for large glasshouses producing tomatoes and capsicums for the Japanese market. Biomass from the glasshouses feeds a worm farm, which in turn makes compost for beef and dairy pastures. Environmental variables for the whole operation are closely monitored, and it is run on long-term quadruple bottom-line principles. The social dividend comes in employment as well as returns for the landholders.

\footnotetext{
0 Ibid., 46.

71 Levy, Grasslands of New Zealand, xxix.

72 Latour, Down to Earth, 42.

73 R. Le Heron and M. Roche, 'The taniwha economy', in Pawson et al., The New Biological Economy, 157-76.

74 Rowarth, Doughnut Economics.
} 
Despite being thoroughly contemporary examples of terrestrial dwelling, examples like this fly beneath the radar as they do not fit with the stories of the improvers. But they are also consistent with tribal cultural values. The emphasis that Ngäi Tahu, which has built one of the biggest corporations operating in the South Island, places on the recovery and fostering of mahinga kai food gathering places and practices illustrates this. ${ }^{75}$ To do so is to be alert to both histories of place and natural rhythms and events, or as Libby Robin puts it in an Australian context: 'detail is the new big picture'. She was referring to the need for 'real "on the ground" detail' to make sense of arid Australia, with its 'variable microclimates, whose very biodiversity is dynamic and spatially unpredictable. ${ }^{76}$ In this context, traditional Aboriginal land management of what was wilderness to Europeans relied on controlled use of fire. People evolved a coordinated 'mosaic pattern of low-level burns', according to the specific requirements of particular areas. ${ }^{77}$ The imposition of the mechanics of European enclosure on country greatly inhibited these practices, with consequences, exacerbated by the impacts of climate change, that have been all too apparent in the terrifying fire season of 2019-20.

Enclosed landscapes can however be redrawn. ${ }^{78}$ This is already happening in some parts of rural New Zealand, now that the focus that Levy placed on productivism is less all-consuming. In places such as Banks Peninsula, Canterbury, the land is being managed in mosaics, aligned to conditions, with pastoral use intensifying in more usable areas such as valley floors. Meanwhile steep, less accessible valley sides are allowed to revert to what not long since would have been called 'scrub' (regenerating bush), but which is now valued for a range of ecosystem services. Increasingly, these include an intergenerational valuation of the indigenous, in the form of covenants in perpetuity registered with either the Queen Elizabeth II National Trust, or a local agency created by landholders for this purpose, the Banks Peninsula Conservation Trust. The result is the emergence of a form of 'middle landscape', integrating the garden and the wild. ${ }^{79}$ Similar renegotiations of how to dwell on the land are occurring elsewhere: a quarter of New Zealand's native vegetation cover is on sheep and beef farms, providing vital biodiversity and carbon sequestration functions. ${ }^{80}$

75 M. J. Stevens, 'Ngāi Tahu and the "nature" of Māori modernity', in Making a New Land, ed. Pawson and Brooking, 293-309.

76 L. Robin, How a Continent Created a Nation (Sydney: UNSW Press, 2007), 121.

77 B. Pascoe, Dark Emu: Aboriginal Australia and the Birth of Agriculture (Broome, WA: Magabala Books, 2014), 116.

78 C. D. Meurk and S. R. Swaffield, 'A landscape ecological framework for indigenous regeneration in rural New Zealand-Aotearoa', Landscape and Urban Planning 50 (2000): 129-44.

79 E. Pawson and A. A. Christensen, 'Landscapes of the Anthropocene: From dominion to dependence?', In Rethinking Invasion Ecologies from the Environmental Humanities, ed. J. Frawley and I. McCalman (London: Routledge, 2014). 65-83.

80 D. Norton and J. Pannell, 'Desk-top assessment of native vegetation on New Zealand sheep and beef farms' (13 June 2018), beeflambnz.com/sites/default/files/FINAL\%20Norton\%20Vegetation\%20occurence\%20 sheep $\% 20$ beef\%20farms.pdf, accessed 27 January 2020. 
The implications of such trends are potentially profound. First, they point towards ways to respond to the need to curb human enthusiasm for meat eating, in order to preserve carbon sinks and curtail greenhouse emissions from stock. ${ }^{81}$ This need not mean any loss to pastoral farmers, but rather could reposition meat as a high-value product, provenanced to the climate-proofing attributes of its place of production. Second, they provide options for managing New Zealand's response to climate change. Both New Zealand's Productivity Commission ${ }^{82}$ and Parliamentary Commissioner for the Environment ${ }^{83}$ argue that this will require radical land use change over the medium term. Both imply the need for top-down reductionist planning, which runs the risk of supplementing empires of grass with serried empires of trees in conventional style. But emerging middle landscapes show the benefits of recognising local terrestrial initiatives, something that could well be extended from rural to city environments. Not only would this engage urban communities with tree planting and biodiversity management, which cities such as New York have already pioneered ${ }^{84}$ it would also extend the opportunity for everyone to land and to live as terrestrials, taking seriously the moral obligation of meeting climate change targets.

\section{Conclusion}

In the early years of environmental history teaching at the University of Otago, Tom Brooking won support to bring a succession of renowned overseas scholars to Dunedin for academic visits. One, William Cronon, known for his reflection on the value of stories, once suggested that 'the task of environmental history is to assert that stories about the past are better ... if they increase our attention to nature and to the place of people within it', and encourage us to look at these in new ways. ${ }^{85}$ So how does environmental history help us to think about a future in the Anthropocene?

First, it shows that there are many precedents for caring for land, landscape and the Earth, and accounts that narrate nature in quite different ways to the paradigm of human domination and exploitation. In New Zealand, Guthrie-Smith and

81 H. Harwatt, 'Including animal to plant protein shifts in climate change mitigation policy: A proposed threestep strategy', Climate Policy 19 (2018): 533-41; M. Springmann et al., 'Options for keeping the food system within environmental limits', Nature 562 (2018): 519-25.

82 New Zealand Productivity Commission, Low-emissions Economy: Final Report August 2018, productivity. govt.nz/assets/Documents/4e01d69a83/Productivity-Commission_Low-emissions-economy_Final-Report.pdf, accessed 27 January 2020

83 Parliamentary Commissioner for the Environment, Farms, Forests and Fossil Fuels: The Next Great Landscape Transformation? (Wellington: Parliamentary Commissioner for the Environment, 2019).

84 D. R. Fisher, E. S. Svendsen and J. J. T. Connolly, Urban Environmental Stewardship and Civic Engagement: How Planting Trees Strengthens the Roots of Democracy (London: Routledge, 2015).

85 W. Cronon, 'A place for stories: Nature, history, and narrative', Journal of American History 78 (1992): 1375. 
Cumberland are 2 examples, the former a particularly potent figure for environmental historians-as Cronon himself ${ }^{86}$ observed — not least because he lived to question whether 'improvement' should be reframed as 'desecration'. More significant are those countless individuals and communities who see value in working with the indigenous, providing social opportunity for all who are willing to attempt to dwell terrestrially. Second, and surely the main historical insight, is that the heroic acts of 'improvement', such as clearing the bush and draining the swamp in order to create empires of grass, were understood as morally improving quests, as actions consistent with and reinforcing economic survival, social reproduction and cultural meaning. They were unquestioningly part of what was then seen as 'the common good'.$^{87}$ That economic growth has been legitimated in the same way does much to explain the timing and vigour of the Great Acceleration. Negotiating a new sense of common good in risky and disconcerting Anthropocene times is therefore of insistent urgency if human potential is now to be safeguarded. ${ }^{88}$

In one of the team meetings in the 'Empires of grass' project, ${ }^{89}$ the question was raised of what environmental history can teach us about the future. I was then, as now, sceptical that it could teach much of immediate value to that end, but the question has stuck in my mind. This article has been a concerted attempt to engage with it. If there is an answer, it is that we now have little choice but to reimagine our collective interests as Earth inhabitants to take full account of those of future, as well as disadvantaged, generations, and those of non-human as well as the human species. This is a compelling moral issue, one that requires honesty, consistency and a willingness both to look and to see. Environmental historians would seem well equipped on each of these grounds. I am forever grateful for the generosity with which Tom has welcomed me into their number, since my first encounter with the poster from the New Zealand Journal of Agriculture cover in his departmental lift more than 20 years ago!

\section{Acknowledgements}

I am grateful to Hugh Campbell, Andreas Aagaard Christensen, Colin Meurk and Harvey C. Perkins for their stimulating comments and encouragement, and to Tim Nolan for drawing Figure 2.

86 W. Cronon, 'Foreword: A passion for small things', in Guthrie-Smith, Tutira, xi-xv.

87 Reich, The Common Good.

88 Ord, The Precipice.

89 Brooking and Pawson, Seeds of Empire. 
This text is taken from International Review of Environmental History, Volume 6, Issue 2, 2020, edited by James Beattie, published 2020 by ANU Press, The Australian National University, Canberra, Australia.

doi.org/10.22459/IREH.06.02.2020.04 